\title{
Механические свойства
}

\section{и эксплуатационные качества} артиллерийских установок, используемых в римских легионах

\section{Ч. Росси}

Университет Неаполя (Федерико II), 80125, Италия, Неаполь, Клаудио прт., д. 21

\section{Mechanical Behaviour and Perfomances of the Artillery of the Roman Legions}

\author{
C. Rossi \\ University of Napoli «Federico II», 80125, Via Claudio, 21, Napoli, Campania, Italy \\ e-mail: cesare.rossi@unina.it
}

В статье описывается механическое действие метательных машин, используемых в римских легионах. Статья начинается с обзора тех исследований, которые были проведены автором за последние 15 лет, иногда в сотрудничестве с некоторыми коллегами. В выводах содержатся (почти) окончательные результаты изучения античных метательных машин как одного из направлений общего исторического исследования. Представлены машины: баллиста, стреломет, катапульты, повторяющиеся катапульты и карробаллиста. Были рассмотрены образцы артиллерии с прямой и высоко выгнутой траекторией полета снарядов. Эти машины относятся к периоду, начиная от II века до н.э., и заканчивая падением империи в V веке н.э., но, главным образом, принадлежат к имперской римской армии.

Ключевые слова: дизайн (конструкция) античных машин, римская артиллерия, машинная терминология.

The mechanical behavior and the performances of the throwing machines used by the Roman Legions ares presented. The paper starts from a synopsis of the studies that were carried on by the author, sometimes in cooperation with some colleagues, in the last 15 years on ancient throwing machines and represent the (almost) final results of this branch of his researches. The presented machines are: the ballista, the catapult, the repeating catapult, the carroballista and the onager. So, both direct firing and high arching artillery was considered. These machines belong to a period of time ranging from the II Century B.C. to the fall of the Empire in V Century A.D., but mostly belong to the Imperial Roman Armies.

Keywords: Ancient machines design, Roman artillery, Machine terminology.

Introduction. It is commonly thought that the very brilliant military campaigns that permitted to the Romans to conquer and hold the largest empire of ancient times was essentially due to their high expertise in tactics and strategy and to well-trained soldiers. This is certainly true but that ones were not the only reasons: together with well-trained and brave soldiers and with brilliant commanders, the «key» for those brilliant military campaigns was also an advanced technology. The possibility of rapidly build roads permitted to quickly move the legions, while the wide number of different war machines including rams, siege towers and other siege engines, throwing machines etcetera gave the 
legions a big advantage. Neglecting these aspects, it is difficult to understand many things about ancient history.

Among these engines, particularly interesting are the throwing machines that represented the ancient artillery, both light and heavy, with pieces to be used in the sieges for static warfare and pieces to be used in open field battles as heavy artillery and as infantry support gun or battalion gun. This is why so many authors (see e.g. [1-23]) have studied ancient throwing machines.

So, it can be seemed interesting to deepen the study of both kinematics and dynamics of these machines and hence to assess their performance.

In the next sections, the following throwing machines will be presented: the euthytone ballista, the palintone ballista, the catapult, the repeating catapult, the carroballista and the onager.

It must be considered that these studies permitted to assess the dynamical behavior of those machines and their performances for the first time.

The studies were essentially conceived as follows:

- Dynamical models and kinematic models of the machines were formulated $[2,5,10,23]$.

- The model of the torsion motor that was formulated just for this purpose [1].

- The results were checked by observing the paths of the ballista balls in the walls of Pompeii and by observing the position of the onagrum balls found inside the city. These, as known, are the remains of the siege of Pompeii by Lucius Silla.

- The virtual (depicted in some of the figures included) and mechanical reconstructions of those machines were mainly based on own authors' studies of the classics (historians and engineers of the Classic Age) and, sometimes, on our own translation of pieces by those classics.

- Some of those machines were build, in full scale, by dr. Russo and the author for Italian $\mathrm{Mu}$ seums etc.

Since the main part of these machines was the motor, it can be interesting to examine this component first.

The Torsion Motor. According to [2, 3] the Greeks from Syracuse developed the first throwing machines using torsion motor. This motor was much more advanced and powerful that the older ones based on the flexion of an elastic leaf (like in the bows) and consisted of a strong wooden square frame, reinforced by iron straps, divided into three separate sections. The central section was used to insert the shaft of the weapons, while the sides were for the two coils. These coils were made by a bundle of elastic fibers; the most widely used fibers were women's hair [24]. The hairs of Caucasian women aging 20-30 years old are, In fact, the natural fibers having the best mechanical properties [24].

As far as the use of women's hair is concerned, the following pieces (and author's translation in English) from the classic can be considered.

Vitruvius, De Architectura liber X, caput XI [25].

Nam quae fiunt in capitibus foramina, per quorum spatia contenduntur capillo maxime muliebri vel nervo funes, magnitudine ponderis lapidis, quem debet ea ballista mittere, ex ratione gravitatis proportione sumuntur, quemadmodum catapultis de longitudinibus sagittarum.

In fact, holes are made in the mainframe and through them are brought the cords, made mostly of woman's hair or of sinews, which are proportioned to the weight of the stone that the ballista must throw and a ratio between weights and lengths is taken in the same manner in which (it is done) with the catapults for the length of the arrows.

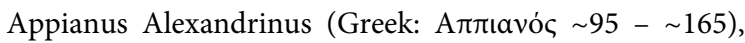
Wars against Carthage, liber VIII, caput XCIII. [26]

Efficientbantque singulis diebus clypeus centum, trecentos gladios; tela quae ex catapultis mittuntur, mille; tragulas et lanceas quigentas; catapultas, quotot poterant: quas ut tendere possent, raserunt feminas, quum aliorum pilorum esset inopia.

Each day they made 100 shields, 300 swords, 1,000 missiles for catapults, 500 darts and javelins, and as many catapults as they could. For strings to bend them the women cut off their hair for want of other fibers.

In Fig. 1 a motor of a Roman catapult is shown; on the left a remain found in Xantem, Germany is reported, in the middle an authors' pictorial exploded view $[1,2]$ and the bundle on the right.

The design of the Greek-Roman throwing machines was based on a module, i.e. the diameter of

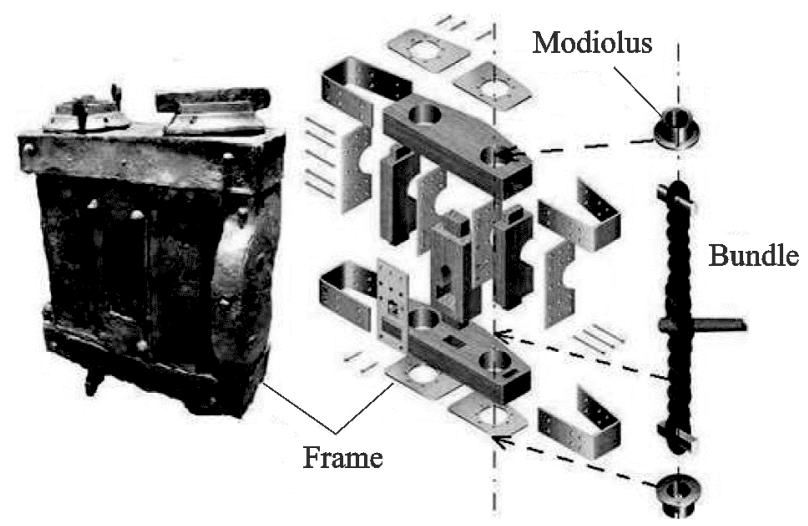

Fig. 1. Propulsor of a Roman catapult; remains (left) and virtual reconstruction (right). Adapted from [2] 

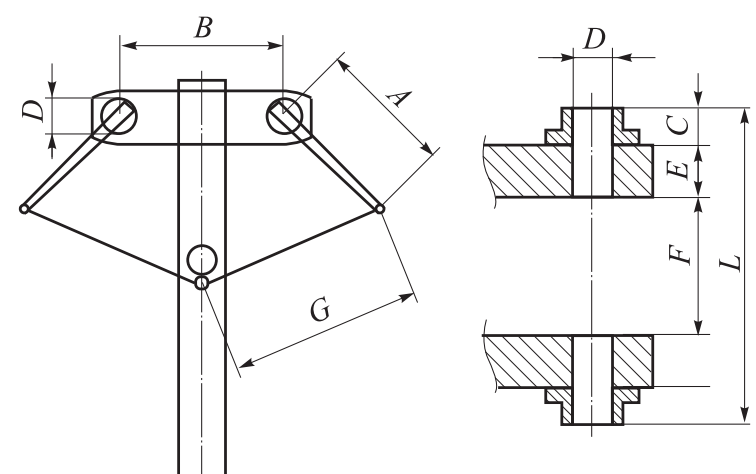

Fig. 2. Scheme of a ballista. Adapted from [1]

the modiolus marked in Figs. 1 and 2. Probably the first ancient scientist who stated the relationship between the weight of the projectile and the modulus diameter was Archimedes of Syracuse. From Philon of Byzantium [27] to Vitruvius [25], all the throwing machines designer and theoreticians say that this relationship is:

$$
D=1,1 \sqrt[3]{100 m} .
$$

Where:

$D$ is the diameter of the modiolus (hence of the hair bundle) in digits ( 1 digit $\approx 19,5$ millimeters) $\mathrm{m}$ is the mass of the projectile in mine ( $1 \mathrm{mina} \approx 431$ grams).

In figure 2 a scheme of the whole machine is reported.

Vitruvius [24] is very meticulous in giving the ratios between the diameter of the modiolus and all the other main dimensions of the machine:

$$
\begin{aligned}
& A=7 D . \\
& B=3+1 / 4 D . \\
& C \sim 0,5 D \text { (this datum is deduced by some rel- }
\end{aligned}
$$
icts).

$E=1 D$.

$F=4 D$.

$d_{1}=9 / 16 D$, diameter of the arm near the bundle.

$d_{2}=7 / 16 D$, diameter of the arm near the rope.

What above clearly shows that ancient engineers designed their machines by adopting a modular design concept.

The Model of the Elastic Bundle. The model of the bundle of hairs representing the torsion motor was presented in [1] so just the main results are summarized. It must be observed that, being the motor a bundle of yarns, it cannot be studied by the common structural mechanics equations.

The elastic energy $L$ stored in an hair bundle is:

$$
\begin{gathered}
L=\int_{0}^{R} L_{i}=E \pi l_{0} \int_{0}^{R}\left(\sqrt{\frac{r^{2} \theta^{2}}{l_{0}^{2}}+1}-1\right)^{2} r d r= \\
=E \pi l_{0}\left[\frac{R^{4} \theta^{2}}{4 l_{0}^{2}}+R^{2}-\frac{2 l_{0}^{2}}{3 \theta^{2}}\left(\frac{R^{4} \theta^{2}}{l_{0}^{2}}+1\right)^{3 / 2}+\frac{2 l_{0}^{2}}{3 \theta^{2}}\right]= \\
=E \pi l_{0} f_{1}(\theta) .
\end{gathered}
$$

Where:

$R$ is the radius of the bundle (hence of the modiolus);

$r$ is the distance of a generic fiber from the bundle axis;

$E$ is the Young's modulus of the hair yarns;

$l_{0}$ is the half of the length of the bundle;

$\theta$ is the torsion of the bundle, given by the machine arms rotation and by the preload.

And the couple $C$ exerted by the torsional motor is:

$$
\begin{aligned}
C=\frac{d L}{d \theta}=2 E \pi l_{0} & {\left[\frac{R^{4} \theta}{2 l_{0}^{2}}-\frac{4 l_{0}^{2}}{3 \theta^{3}}+\frac{4 l_{0}^{2}}{3 \theta^{3}}\left(\frac{R^{2} \theta^{2}}{l_{0}^{2}}+1\right)^{3 / 2}-\right.} \\
& \left.-\frac{2 R^{2}}{\theta}\left(\frac{R^{2} \theta^{2}}{l_{0}^{2}}+1\right)^{1 / 2}\right] .
\end{aligned}
$$

The $L / D$ ratio between the length of the bundle and its diameter was decisive for obtaining the maximum energy from the bundle itself without exceeding the hair stress proportionality limit. It can be computed by [1]:

$$
\begin{gathered}
L / D=\sqrt{\frac{\theta^{2}}{\left(\sigma_{e} / E^{\prime}+1\right)^{2}-1}} \cong \sqrt{\frac{\theta^{2}}{0,035}} \Rightarrow \\
\theta_{\max } \cong 10,7 L / D(\mathrm{deg}) .
\end{gathered}
$$

Were $\sigma_{e}^{\prime}$ represents the hair yarns stress proportional limit. It was found that all the torsion motor throwing machines were designed with the $L / D$ ratio that permitted to achieve this stress proportionality limit at the maximum arms rotation for each kind of machine [1].

The Ballista. In ancient times, the term «ballista» indicated a stone or lead projectiles throwing machine while the term «catapult» indicated a big arrows (or javelins) throwing machines. During the Middle Ages, these two terms were used in the opposite meaning; the author doesn't know the reason. In the following, the ancient meaning is adopted.

Ballistae were designed according to two different mechanical schemes: an earlier one called «eu- 
titonon» or «euthytone» and a later one called «palintonon» or «palintone».

Euthytone Ballista. In Fig. 3 a pictorial reconstruction of the ballista $[1,2]$, based on the treatise by Vitruvius $[25,28,29]$ is shown.

The euthytone scheme adopted arms located outside the motor frame as shown in figs. 2 and 3.

In order to compute the machine performances, the scheme shown in fig. 4 was considered.

By differentiating the equations that give the projectile displacement $S_{c}$ as a function of the arms rotation the arm position $\theta$ :

$$
\begin{gathered}
S_{C}=a\left[\sqrt{(\mu+1)^{2}-\varepsilon^{2}}-\cos \theta-\sqrt{\mu^{2}-(\sin \theta+\varepsilon)^{2}}\right]= \\
=a f_{2}(\theta),
\end{gathered}
$$

the projectile velocity $V_{c}$ as a function of $\theta$ and of the arm velocity $\dot{\theta}$, is obtained:

$$
V_{C, \text { eut }}=a \dot{\theta}\left[\sin \theta+\frac{\sin 2 \theta+2 \varepsilon \cos \theta}{2 \sqrt{\mu^{2}-(\sin \theta+\varepsilon)^{2}}}\right]=
$$

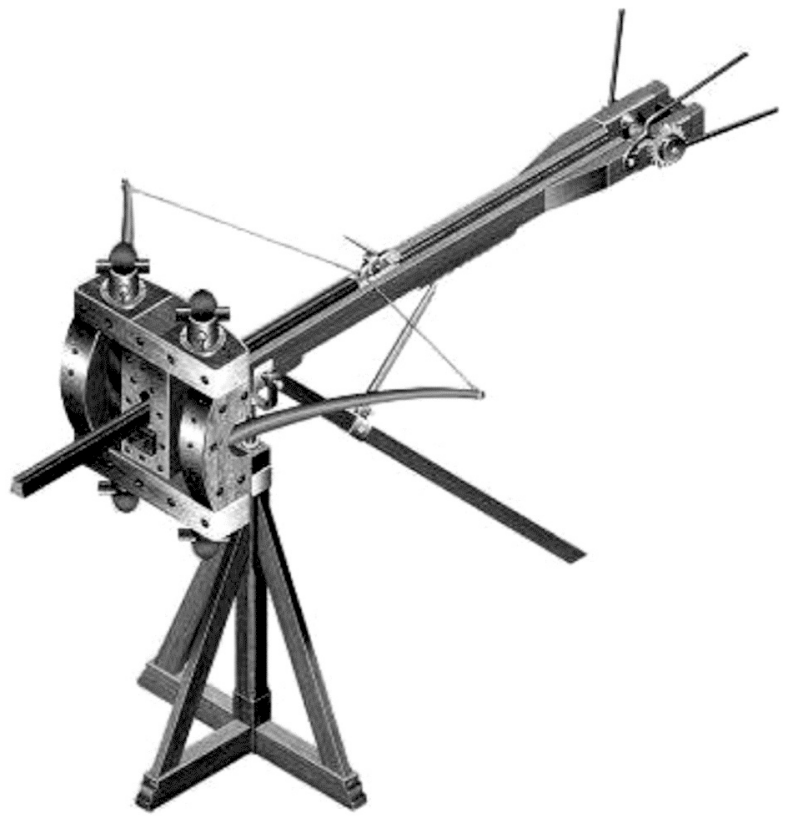

Fig. 3. Pictorial reconstruction of the ballista of Vitruvius. Adapted from [2]

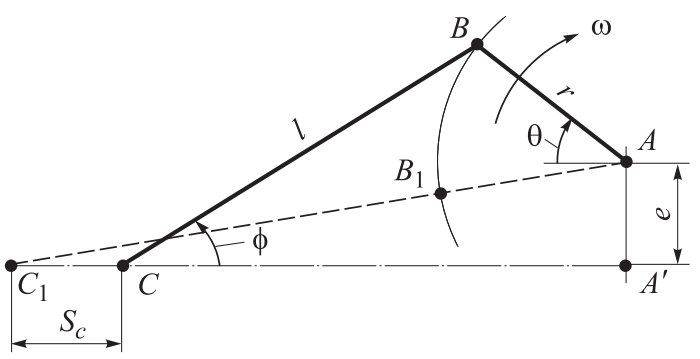

Fig. 4. Euthytone kinematic scheme

$$
=a \dot{\theta} f_{3}(\theta) .
$$

Where $\mu$ is the $1 / r$ ratio and $\varepsilon$ the $e / r$ ratio (see fig. 4).

The energy balance between the potential elastic energy of the bundles and the kinetic energy of the projectile and of the machine moving elements is:

$$
E_{\text {cin }}=L-L_{\text {attr }} \text {. }
$$

Where:

$E_{c i n}$ is the kinetic energy of the moving components of the machine,

$L$ is the elastic energy of the bundle, computed by eq. (1),

$L_{a t t r}$ is the energy lost due to the friction between the projectile and its guide.

If we indicate with:

$m$ the projectile mass,

$I_{b}$ the mass moment of inertia of each arm,

$f$ the coefficient of friction between the projectile and the guide, in a generic configuration assigned by the arm rotation $\theta$, the terms of eq. (5) are:

$$
\begin{gathered}
E_{\text {cin }}=\frac{m V_{C}^{2}+2 I_{b} \dot{\theta}^{2}}{2}=\frac{V_{C}^{2}}{2}\left(m+\frac{2 I_{b}}{\left[a f_{3}(\theta)\right]^{2}}\right) ; \\
L=4 E \pi l_{0}\left[f_{1}\left(\theta_{0}-\theta_{\text {in }}\right)-f_{1}\left(\theta-\theta_{\text {in }}\right)\right] ; \\
L_{\text {attr }}=m g f S_{C}=m g f a\left[f_{2}(\theta)-f_{2}\left(\theta_{\text {in }}\right)\right] .
\end{gathered}
$$

So:

$$
\begin{gathered}
\frac{1}{2} V_{C}^{2}\left(m+\frac{2 I_{b}}{\left[a f_{3}(\theta)\right]^{2}}\right)= \\
=4 E \pi l_{0}\left[f_{1}\left(\theta_{0}-\theta_{\text {in }}\right)-f_{1}\left(\theta-\theta_{\text {in }}\right)\right]+ \\
+m g f a\left[f_{2}(\theta)-f_{2}\left(\theta_{\text {in }}\right)\right] .
\end{gathered}
$$

The quantities $f_{1}, f_{2}$ and $f_{3}$ are given by equations (1), (4) and (5) respectively.

From the previous equations, we obtain:

$$
\begin{aligned}
V_{C}= & 2\left\{\frac{4 E \pi l_{0}\left[f_{1}\left(\theta_{i n}-\theta_{0}\right)-f_{1}\left(\theta-\theta_{i n}\right)\right]}{m+2 I_{b} /\left[a f_{3}(\theta)\right]^{2}}-\right. \\
& \left.-\frac{m g f a\left[f_{2}(\theta)-f_{2}\left(\theta_{i n}\right)\right]}{m+2 I_{b} /\left[a f_{3}(\theta)\right]^{2}}\right\}^{1 / 2} .
\end{aligned}
$$

Equation (14) permits to compute the projectile velocity for any given arm angle $\theta$, hence when it leaves the machine [1].

It must be observed that this dynamical model permits to compute projectile velocity without solving differential equations, but directly in close analytical form.

It was found that for these kind of machines, the initial velocity was around $100 \mathrm{~m} / \mathrm{s}$. 


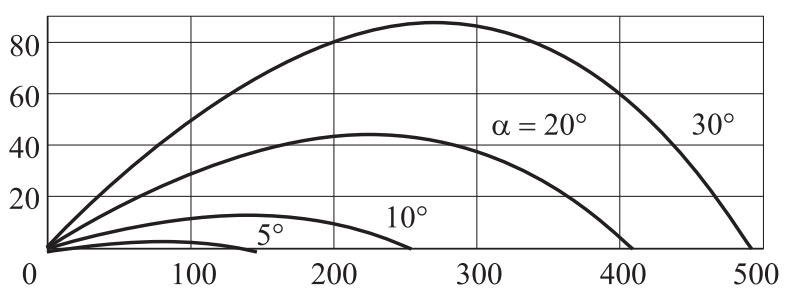

Fig. 5. Examples of trajectories for the euthytone

In Fig. 5 are reported the trajectories, computed by considering the air friction, of a stone projectile which mass is 10 Roman minae $(=4,36 \mathrm{~kg})$ and having $95 \mathrm{~m} / \mathrm{s}$ initial velocity, thrown with different elevation angles.

How it is possible to observe this machine showed remarkable performances and rather flat trajectories.

Palintone Ballista. According to several authors (see e.g. $[4,8,19,20]$ ), around II Century B.C., an important improvement in the throwing machine design took place. These machines had the arms fitted inside the main frame as shown in Fig. 6.

This design permitted to reach larger arms rotations, hence better performances [5].

The kinematics and the dynamics of this machine was studied [5] in a similar way as described for the euthytone.

In Fig. 7 are reported the trajectories of a stone projectile which mass is 50 minae $(=21,8 \mathrm{~kg})$ thrown by a large palintone at $118 \mathrm{~m} / \mathrm{s}$ initial velocity.

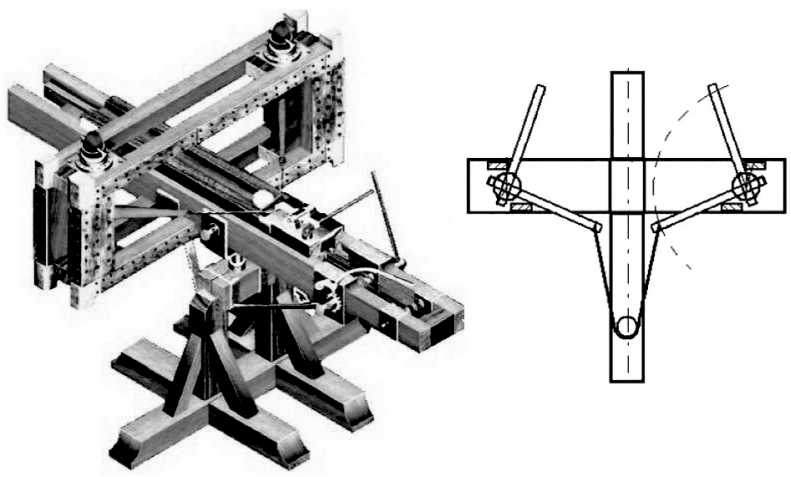

Fig. 6. Palintonon: pictorial reconstruction and scheme

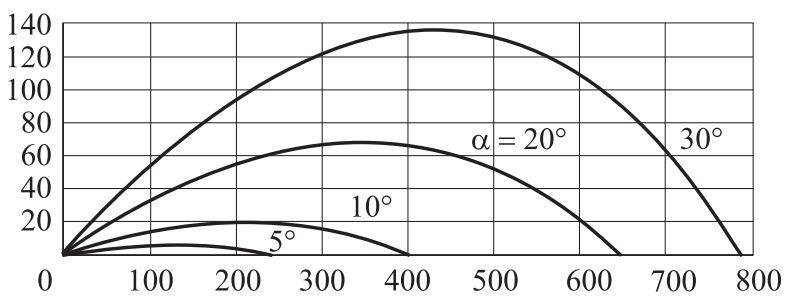

Fig. 7. Trajectories for a large Palintone
Table 1

Palintone ballista range figures; projectile mass $=21,8 \mathrm{~kg}$, initial velocity $118 \mathrm{~m} / \mathrm{s}$

\begin{tabular}{|c|c|c|c|c|c|}
\hline$\theta(\mathrm{deg})$ & Range $(\mathrm{m})$ & $h_{\max }(\mathrm{m})$ & $V_{f}(\mathrm{~m} / \mathrm{s})$ & $\beta(\mathrm{deg})$ & $T_{f}(\mathrm{~s})$ \\
\hline 5 & 221 & 5,1 & 110,7 & 5,5 & 2 \\
\hline 10 & 396,5 & 19,2 & 89,1 & 12 & 4 \\
\hline 20 & 645,1 & 68,7 & 76,6 & 26,5 & 7,5 \\
\hline 30 & 785,5 & 137,6 & 73 & 40,5 & 10,6 \\
\hline
\end{tabular}

An example of computed range figures of these large machines is reported in Table 1.

In the table are reported:

- the angle of elevation $\theta$,

- the range,

- the maximum height reached by the projectile $h_{\max }$,

- the velocity at the impact $V_{f}$,

- the angle at the impact $\beta$,

- the time of flight $T_{f}$.

Ballistae having the palintone scheme were designed as big as to throw up to $33 \mathrm{~kg}$ projectiles.

The Catapult. As told in the previous paragraph, in ancient times the term "catapult» indicated a big arrow throwing machine. This kind of machine was also called by the Romans «scorpio» (=scorpion).

From a mechanical point of view, a common catapult didn't significantly differ from a ballista. According to ancient engineers, calculations were made starting from the length of the arrow. If the latter is indicated with $S$, the diameter of the modiolus is:

$$
D=S / 9 .
$$

The ratios between the diameter of the modiolus and all the other main dimensions of the machine are the same that were already considered.

Much more interesting are some particular examples of scorpio: the repeating catapult and the carrobalista.

The Repeating Catapult. The invention of the repeating catapult is tributed to Dionysius of Alexandria, (III Century B.C.) and was described by Philon of Byzantium [2, 6, 7, 27, 30-32]. It can be considered as a concentration of the most advanced mechanical kinematic and automatic systems of the time, many of which are still widely used. According to the author's reconstruction [10], based on previous works and from the description by Philon [27], the device is really auto- 


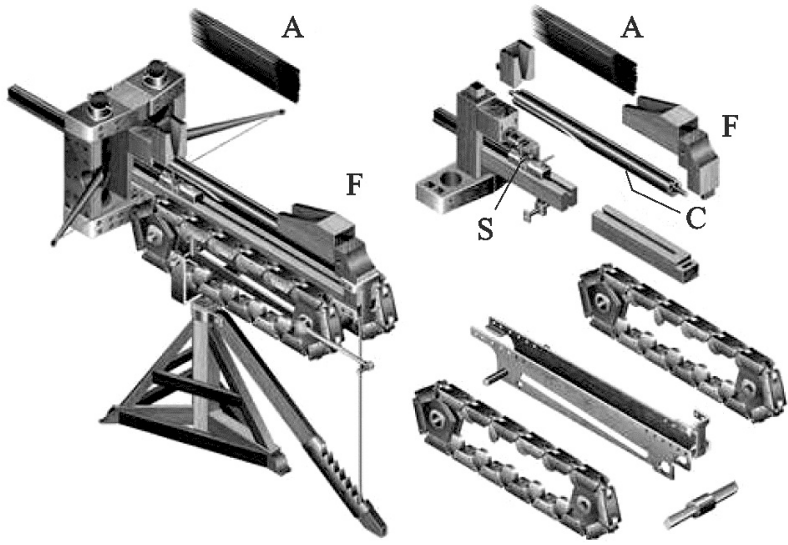

Fig. 8. Pictorial reconstruction of the repeating catapult. Adapted from $[2,10]$
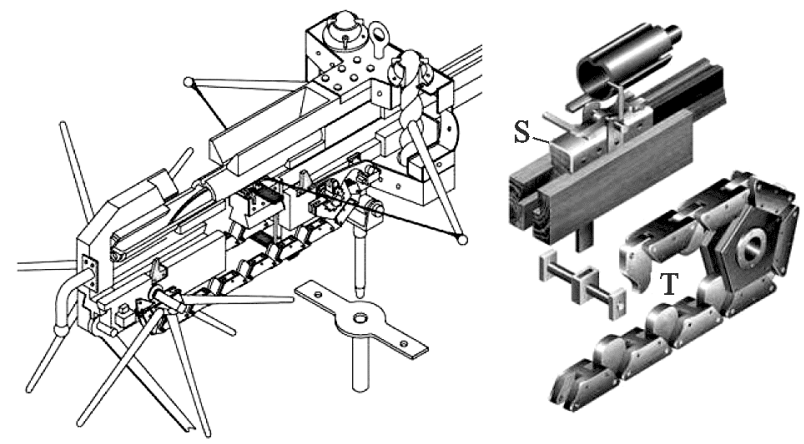

Fig. 9. Views of the reconstruction of the repeating catapult. Adapted from $[2,10]$

matic. A pictorial reconstruction of it is shown in Figs. 8 and 9. The device essentially consisted in a container holding within it a number of arrows, a cylinder feeding device and movement chain. According to Philon, the arrows were located in a vertical feeder $F$ and were transferred one at a time into the firing groove by means of a rotating cylin$\operatorname{der} C$, activated alternatively by a guided cam, in turn activated by a slide. One of the longer interior teeth $\mathrm{T}$ of the chain pulls the slide $S$ which in turn pulled the cord, loading the coils of the motor. In the same time, an attached cam caused a $180^{\circ}$ rotation in the direction of the cylinder, drawing an arrow from the loader and placing it in the channel in front of the rope. When the slide reached the rear of the weapon, the $\operatorname{cog}$ released it, while another opened the release mechanisms. An instant later, upon completion of sprocket rotation, the same cog coupled with the slide from underneath, pulling in the opposite direction. Near the top of the weapon, the second device closed the hook after it had retrieved the cord, while the feeder cylinder picked up another arrow from the feeder. A half rotation in the sprocket and the cycle was repeated.
It must be observed that our reconstruction [5], based on our translation of text by Philon, is really automatic; this because, differently by previous reconstructions $[7,12,13]$, a simple rotation of the crank was sufficient to move the cylinder, the slide, the slide hooking mechanism and the trigger mechanism.

This repeating scorpio threw arrows $485 \mathrm{~mm}$ long. Supposing these arrows had a section of a circle of $32 \mathrm{~mm}$, an air drag coefficient $C_{x}=0,35$, weighted among $150 \mathrm{~g}$ and had an initial velocity of $65 \mathrm{~m} / \mathrm{s}$ [1], the trajectories reported in Fig. 10 can be computed.

From the figure it comes that this was a really suitable machine that, throwing almost 10 arrows per minute, could give an appreciable battlefield coverage.

The Carroballista. The carroballista was a lightweight and cart mounted war machine represented a powerful and effective artillery piece for the Roman Imperial Legions. Almost 24 of these light artillery pieces were assigned to each legion, representing the first example of close support artillery.

Based on some bas reliefs on the Trajan Column and the Aurelian Column and on the investigations of some author's previous studies $[1,2,5$, and on several investigations by other Authors [14, $22,33]$, the authors [34] supposed that this ballista (see Fig. 11) was based on a palintone design, as already suggested in $[8,14,15,18,22,33]$. This

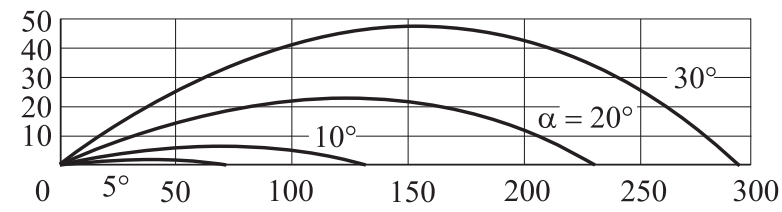

Fig. 10. Trajectories of the repeating catapult arrows
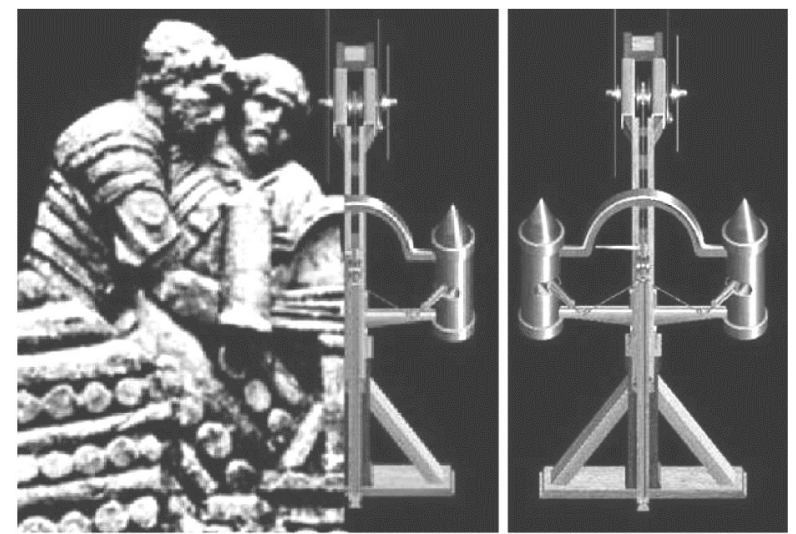

Fig. 11. Bas relief and scheme of the machine. Adapted from [23] 


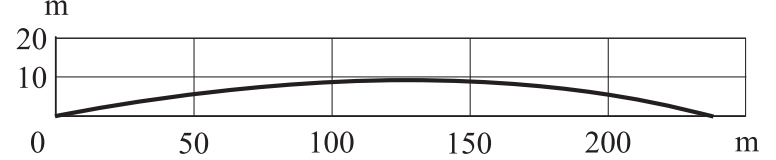

Fig. 12. Trajectory of a bolt of the cheirobalista

design, in fact, seems reasonable to suppose for a machine that should develop enough power in small dimensions.

According to $[22,33]$ the author suppose that the most probable motor was made up by steel helical torsion spring that replaced the hair bundle in this kind of machine [34]. By means of a mathematical model of the machine, the mechanical behavior of the machine itself and hence the range figures of possible projectiles were computed. The possible projectile were $a \approx 200$ gram lead ball or a bolt having almost the same mass.

In fig. 12 are reported the bolt trajectories for an elevation angle of $7,5^{\circ}$. How it is possible to observe, the trajectories is rather flat; this means a rather high possibility to hit the target even for little errors in estimating the real distance of the target itself.

Finally it must be remarked It is also surprising the modernity of the concept that consists in providing the legions of a battalion gun for close support about 1900 years ago $[35,36]$.

The Onager. The term «onager» comes from the Latin «onagrum» that means donkey. The Greek name of this machine was «monoanchon», literally indicating a single arm machine. Although it is a very interesting throwing machine, rather few investigations $[7,8,19,37]$ were carried on it. Unlike the previously described machines that gave the projectile a flat trajectory, the onager was an high arcing throwing machine that was comparable to modern howitzers. In figure 13 a virtual reconstruction is shown.

The working principle is shown in fig. 14 [38].

From figs. 13 and 14 the machine and it's working principle can be understood. Essentially the machine was composed by a single arm ( $A$ in Fig. 12) that is inserted in a hairs bundle, representing the torsion motor of the machine and giving an elastic couple ( $C$ in fig. 13) to the arm. The bundle can be preloaded by means of the modioli $M$ (Fig. 12). On the other end of the arm, a sling is liked (which kinematic length is indicated with $l_{2}$ in fig. 13) that holds the projectile. One of the sling ropes is fixed to the arm while the other rope is linked by means of a ring that is put on a pin

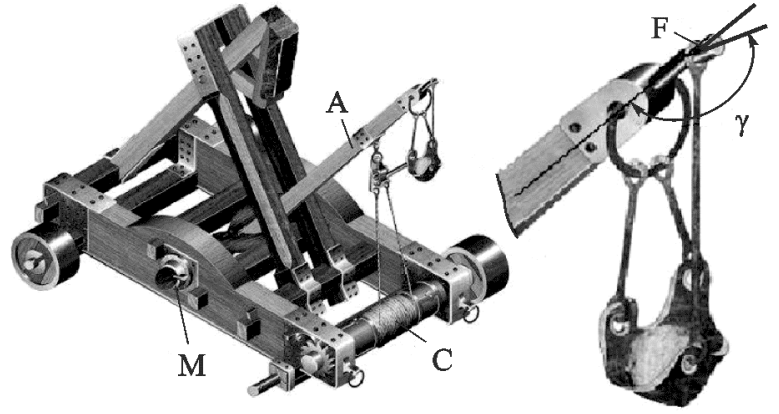

Fig. 13. Virtual reconstruction and a particular of the sling release mechanism of the onager. Adapted from [2]

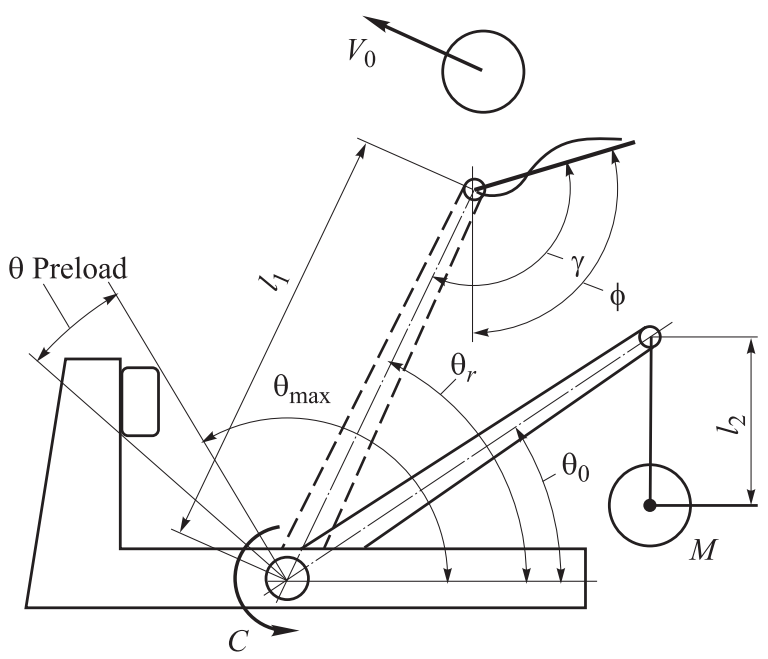

Fig. 14. Working principle of the onager

( $F$ in the particular of fig. 12 ); the axis of this pin can be set with a desired angle $\gamma$ respect to the axis of the arm. Finally, a capstan rotates the arm to charge the torsion spring and, hence, the machine.

When the trigger is pushed, the arm is released and it will rotate because of the couple given by the torsion motor. The projectile will be released by the sling when it's ropes will be approximately aligned with the pin axis since in this condition the ring of the sling will climb over the pin. In this way, by changing the angle $\gamma$, the initial throwing angle of the projectile and its initial velocity can both be set.

The onager was designed to throw rather heavy stone balls, jumping over the walls. It is interesting to note that the range could be adjusted in two different ways:

by changing the angle $\gamma$;

by changing the bundle initial torque, obtaining more «flat» trajectories than the previous ones.

In the figs. 15 and 16 the trajectories of a $17,44 \mathrm{~kg}$ (= 40 Roman minae) stone ball are re- 


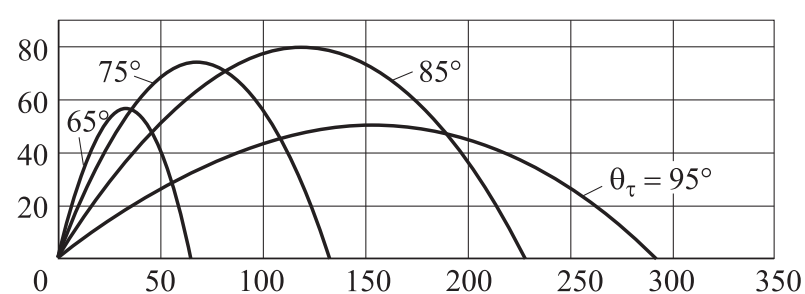

Fig. 15. Trajectories of the Onager; $\theta_{\text {und }}=110^{\circ}$. Adapted from [38]

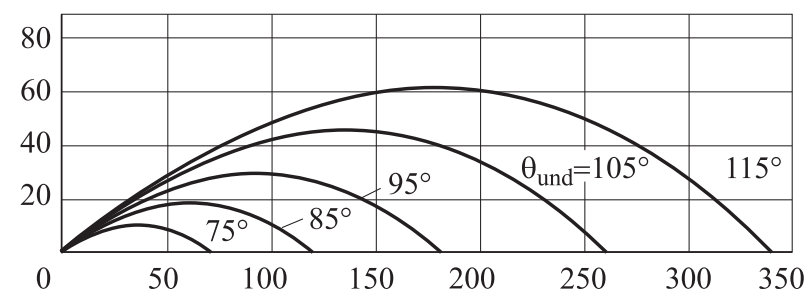

Fig. 16. Trajectories of the Onager; $\theta_{r}=95^{\circ}$

ported. In Fig. 14 the trajectory were obtained by changing the angle $\gamma$ while the bundle initial torsion $\theta_{\text {und }}$ was constant; in the figure the amount of the angle $\gamma$ is reported. In Fig. 15 those obtained by changing the bundle initial preload $\theta_{\text {und }}$ are shown and holding the angle of release $\theta_{r}$ constant.

If a comparison with modern howitzers can be made, we could conclude that the ways to adjust the range essentially corresponds to both a variation of the gun barrel elevation (in the first case) and of the weight of the firing charge (in the second case). This becomes even more evident if the range figures are considered.

Table 2

Onager range figures; $\theta_{\text {und }}=110^{\circ}$

\begin{tabular}{|c|c|c|c|c|c|c|}
\hline $\begin{array}{c}\theta_{r} \\
\left({ }^{\circ}\right.\end{array}$ & $\begin{array}{c}V_{0} \\
(\mathrm{~m} / \mathrm{s})\end{array}$ & $\begin{array}{c}\alpha \\
\left({ }^{\circ}\right)\end{array}$ & $\begin{array}{c}\text { Range } \\
(\mathrm{m})\end{array}$ & $\begin{array}{c}h_{\max } \\
(\mathrm{m})\end{array}$ & $\begin{array}{c}V_{f} \\
(\mathrm{~m} / \mathrm{s})\end{array}$ & $\begin{array}{c}\beta \\
\left({ }^{\circ}\right)\end{array}$ \\
\hline 65 & 35,72 & 73,99 & 63,8 & 57,3 & 33,9 & 74 \\
\hline 75 & 43,66 & 65,1 & 132,2 & 74,6 & 40,2 & 67 \\
\hline 85 & 52,3 & 52,5 & 229,7 & 80,1 & 45,7 & 55,5 \\
\hline 95 & 61,4 & 32,46 & 293,5 & 50,5 & 50,6 & 36,7 \\
\hline
\end{tabular}

Table 3

Onager range figures; $\theta_{r}=9^{\circ}$

\begin{tabular}{|c|c|c|c|c|cc|}
\hline$\theta_{r}\left({ }^{\circ}\right)$ & $\begin{array}{c}V_{0} \\
(\mathrm{~m} / \mathrm{s})\end{array}$ & $\begin{array}{c}\alpha \\
\left({ }^{\circ}\right)\end{array}$ & $\begin{array}{c}\text { Range } \\
(\mathrm{m})\end{array}$ & $\begin{array}{c}h_{\max } \\
(\mathrm{m})\end{array}$ & $\begin{array}{c}V_{f} \\
(\mathrm{~m} / \mathrm{s})\end{array}$ & $\begin{array}{c}\beta \\
\left({ }^{\circ}\right)\end{array}$ \\
\hline 75 & 29,1 & 29,69 & 71,4 & 10,4 & 27,7 & 30,6 \\
\hline 85 & 37,67 & 30,64 & 118,7 & 18,1 & 34,8 & 32,3 \\
\hline 95 & 46,78 & 31,5 & 179,5 & 28,9 & 41,5 & 34 \\
\hline 105 & 56,41 & 32,18 & 252,8 & 42,3 & 47,7 & 35,8 \\
\hline 115 & 66,57 & 32,71 & 337,2 & 59,3 & 53,4 & 37,6 \\
\hline
\end{tabular}

In table 2 and in table 3 are reported the range figures for the cases of figs. 15 and 16 respectively.

All the above shows that the onager was a really effective machine. The study, in fact also shows that it could be even used with the same operating flexibility of modern howitzers.

Conclusions. The results of several previous investigations on ancient throwing machines were presented. The latter are essentially based on functional reconstruction of these machines by the author (that allowed their kinematics and dynamics to be obtained) and also on other Authors' studies.

The author hopes that what above can contribute to understand the following aspects:

The high level that was reached by ancient engineers in mechanical design.

The ancient warfare machines performances.

Some aspects of the ancient military history and tactics.

It must also be noted that, excluding the trebuchet (a giant, non-transportable siege machine invented in the Middle Ages), no throwing machine surpassed the described ancient machines until the gun powder artillery was well developed. Moreover, some of these machines show a surprising modernity as far as the tactic employment is concerned, representing the ancestors of some modern warfare techniques.

It is a pity to consider that mankind used his capabilities mostly in conceiving war machines. Nevertheless, it must be considered that almost all the technology and the devices commonly used in our life were developed starting from military applications [38].

Acknowledgements. The author thanks all his colleagues and friends that very usefully cooperated with him in this kind of studies during the last years.

In particular the author is thankful to:

Dr. Ing. Flavio Russo for almost 15 years of friendly cooperation on researches on ancient technology in general and on Greek-Roman mechanics in particular.

Prof. Antonia Passarelli for his help in analytically solving the integrals related to the model of the hairs bundle torsion motor.

Profs. Stefano Pagano and Arcangelo Messina and Drs. Sergio Savino and Giulio Reina who efficiently cooperates on researches on some of the cited machines. 


\section{References}

[1] Rossi C. Ancient Throwing Machines: a Method to Compute Their Performances. Mechanism and Machine Theory, 2012, vol. 51, pp.1-13.

[2] Rossi C., Russo F., Russo F. Ancient Engineers' Inventions - Precursors of the Present. Springer, 2009, vol. 8, 321 p.

[3] Chondros T.G. Archimedes (287-212 BC) History of Mechanism and Machine Science 1, Distinguished Figures in Mechanism and Machine Science, Their Contributions and Legacies. Part 1. University of Cassino, Italy, Springer, 2007. 392 p.

[4] Chondros T.G. The development of machine design as a science from classical times to modern era HMM 2008, International Symposium on History of Machines and Mechanisms, Proceedings Published by the Springer, November 11-14, 2008, Tainan, Taiwan, Netherland, 2008.

[5] Rossi C., Pagano S. Improvement in ballistae design from eutitonon to palintonon: A study on the mechanical advantages. Journal of Mechanical Design, Transactions of the ASME, 2013, 135(8), art. no. 081006.

[6] Marsden E.W. Greek and Roman Artillery Historical Development, Oxford University Press II, 1969.

[7] Marsden E.W. Greek and roman artillery. Technical treatises, Oxford, 1971, pp. 106-184

[8] Russo F. L'artiglieria delle legioni romane. Istituto Poligrafico e Zecca dello Stato, 2004.

[9] Russo F. Tormenta Navalia. L'artiglieria navale romana, USSM Italian Navy, Roma, 2007.

[10] Rossi C., Russo F. A reconstruction of the Greek-Roman repeating catapult. Mechanism and Machine Theory, 2010, vol. 45, issue 1, pp. 36-45.

[11] Russo F. La grande Balista di Hatra. Ed. ESA, Torre del Greco (Naples), Italy, 2009.

[12] Shramm E. Die antiken Geshützen der Saalburg. Reprint, Bad Homburg, Saalburg Museum, 1980.

[13] Soedel V., Foley V. Ancient Catapults. Scientific American, 1979.

[14] Iriarte A. 'Pseudo-Heron's cheiroballistra a(nother) reconstruction: I. Theoretics'. Journal of Roman Military Equipment Studies, 2000, no. 11, pp. 47-75. Available at: http:// cohorsprimagallica.com/Aitor_Cheiroballistra/Aitor_Iriarte\%27s_Webage.html.

[15] Iriarte A. The Inswinging Theory. Gladius XXIII 2003, pp.111-140.

[16] Baaz D. 'Recent Finds of Ancient Artillery'. Britannia, 1978, no. 9, pp. 1-17.

[17] Bishop M.C., Coulston J.C.N. Roman military equipment from the Punic Wars to the fall of Rome, London, 1993.

[18] Harpham R., Stevenson D.W.W. 'Heron's Cheiroballistra (A Roman Torsion Crossbow). Journal of the Society of Archer-Antiquaries, 1997, 40, pp. 13-17.

[19] Hart V.G., Lewis M.J.T. Mechanics of the Onager. J. of Eng. Math., vol. 20, no. 4, pp. 345365, doi: 10.1007/BF00044610.

[20] Hart V.G., Lewis M.J.T. The Hatra ballista: a secret weapon of the past? J. of Eng. Math., 2009, vol. 67, pp. 261-273, doi: 10.1007/s10665-009-9317-8.

[21] Lahanas M. Ancient Greek Artillery Technology from Catapults to the Architronio Cannon. Available at: http://www.mlahanas.de/Greeks/war/CatapultTypes.htm.

[22] Molari P.G. Angelini G., Canzler A., Sannipoli P. Ricostruzione della balista imperiale Romana - un piacevole viaggio fra fantasia, storia, tecnologia e ... progettazione (Reconstruction of the Imperial Roman Ballista - a pleasant journey through fantasy, history, technology and... design). 2012, p. 40, doi: 10.6092/unibo/amsacta/3306.

[23] Rossi C., Savino S., Messina A., Reina G. Performance of Greek-Roman Artillery. Arms \& Armor, 2015, vol. 12, iss. 1, pp. 67-89, doi: http://dx.doi.org/10.1179/1741612415Z. 00000000050.

[24] Xiao Q., Schirer J., Tsuchiya F., Yang D. Nanotensile Study of Single Human Hair Fiber. Hysitron Incorporated 10025 Valley View Road, Minneapolis MN 55344.

[25] Vitruvius, De Architectura, liber X.

[26] Appianus Alexandrinur Wars against Cartage, liber VIII.

[27] Philo of Byzantium (III Century B.C.) Mechanike syntaxis (Compendium of Mechanics) la parte detta Belopoeica in cui si parla di artiglierie a torsione. 
[28] Cigola M., Ceccarelli M. Machine designs by Vitruvius in reproductions of De Architectura over the time, CD Proceedings on IFToMM Workshop on History of Machine and Mechanism Science, Palermo 21-22 November 2012, paper no.15.

[29] Cigola M, Ceccarelli M., Marcus Vitruvius Pollio (Second Half of the ${ }^{\text {st }}$ Century B.C.), in: Distinguished Figures in Mechanism and Machine Science - Part 3, History of Mechanism and Machine Science, 2014, vol. 26, pp. 307-344. Available at: http://dx.doi.org/ 10.1007/978-94-017-8947-9_15.

[30] Baldi B. (1616) Heronis Ctesibii Belopoeka, hoc est, Telifactiva. Augusta Vindelicorum, typu Davidu Frany.

[31] Shramm E. (1918) Die antiken Geschütze der Saalburg. Reprint, Bad Homburg, Saalburg Museum, 1980.

[32] Soedel V., Foley V. (1979) Ancient Catapults. Scientific American, March 1979.

[33] Molari P.G. (2013) Dal fregio della Colonna Traiana argomenti per ricostruire la balista imperiale romana (From the Friezes of Trajan's Column Arguments to Rebuild the Imperial Roman Ballista). Atti del Convegno. Colonna Traiana MCM - Accademia di Romania in Roma, 7-8 giugno 2013. In press.

[34] Penta F., Rossi C., Savino S. (2014) Mechanical behavior of the imperial carroballista. Mechanism and Machine Theory, vol. 80, pp.142-150.

[35] Russo F., Russo F. (2009) La lezione di Teutoburgo. Archeo, no. 295, pp. 54-61.

[36] Ammianus Marcellinus (IV Century A.D.) Res gestae.

[37] Russo F. (2011) Attenti all'asino. Archeo, no. 311, pp. 90-95.

[38] Messina A., Rossi C. Mechanical Behavior and Performance of the Onager. J. Mech. Des, vol. 137, issue 3, doi:10.1115/1.4029319.

[39] Rossi C. (2013) Guest editorial On Designs by Ancient Engineers. Journal of Mechanical Design, Transactions of the ASME, 135 (6), art. no. 060301. doi:10.1115/1.4024362.

[40] Ceccarelli M., De Paolis P. A Brief Account on Roman Machines and Cultural Frames, Proceedings of HMM2008 - the Third IFToMM International Symposium on History of Machines and Mechanisms, Springer, Dordrecht, 2008, pp. 83-100.

[41] Popescu I., Ceccarelli M. The Machines, Structures, and Mechanisms on the Traian's Columns. The $9^{\text {th }}$ IFToMM International Symposium on Theory of Machines and Mechanisms, Bucharest, 2005, pp. 283-288.

The article received 28.09.2015

\section{Информация об авторе}

РОССИ Чесаре (Неаполь) - профессор по «Мханике машин и механических систем», член правления организации «Итальянская Группа механики машин и механических систем», член правления факультета Промышленной Инженерии Университета Неаполя (Федерико II) (80125, Италия, Неаполь, Клаудио прт., 21, e-mail: cesare.rossi@unina.it).

\section{Information about the author}

ROSSI Cesare (Napoli) - Full Professor of Mechanics for Machines and Mechanical Systems, Member of the Presidence Board of the Italian Group of Mechanics for Machines and Mechanical Systems, Member of the Presidence Board of the Department of Industrial Engineering of the University of Napoli «Federico II» (80125, Via Claudio, 21, Napoli, Campania, Italy, e-mail: cesare.rossi@unina.it). 